\title{
Survival from the Balance of Payment Crisis: Implications from the Challenges Faced by India
}

\author{
Balkrishan Sangvikar, Avinash Pawar, Rajesh Pahurkar
}

\begin{abstract}
Financial crisis has always been a concern for all the countries in the world. The balance of payment crisis has significantly affected India in 1991, which was the worst situation India has ever faced. The crisis has started originating from the fiscal year 1979-80 onwards and continued rising in current account deficit, imports of oil, increased in the growth of imports of goods, decreased in exports, breaking of Soviet-bloc and fiscal indiscipline, all these headed to 1991 balance of payment crisis. However, again in 2012-2013, India's current account deficit grasped to the lowest point as oil and gold imports were ascended. Furthermore, the increase in imports of non-oil goods caused an increase in the current account deficit, which was the highest after the 1991 crisis. Since the situations of 1991 and 2012, India reformed many policies to prevent this financial crisis in future and make stronghold in the global market. This paper explores the overview of the balance of payment situations in 1991 and 2012 with its impact and remedies. The secondary data is collected from the authenticated sources and analysed to derive findings and suggestions regarding the management of balance of payment in the country. The outcome of the paper provides the lessons to avoid this type of crisis of balance of payment by controlling the import and export by reforming government.
\end{abstract}

Keywords: Balance of Payment, Financial Crisis, Financial reforms, Currency Issues, Recession, Foreign Currency, Inflation, Indian Economy.

\section{INTRODUCTION}

India is the largest economy with the highest population. India became an independent nation in 1947, and after that, there was slow-moving progress in the economy. Despite several efforts of the government, the growth of gross domestic product (GDP) was insignificant. However, strategic actions to reform the economy was taken in 1980, which caused capital imports and technological developments. After that, the gulf war started and contributed to a crisis in USSR which resulted in political instability in India. This situation has affected the financial state and resulted in worsening of the economic condition, which resulted in a balance of payment crisis in India. Furthermore, there was an utmost need to improve this situation with economic reforms which was elicited by the balance of payment crisis of 1991. The economic reforms in the form of the policy decision of the government in the form of liberalisation, privatisation and globalisation (LPG) policy

Revised Version Manuscript Received on 16 September, 2019.

Balkrishan Sangvikar*, Department of Management Sciences, Savitribai Phule Pune University, India

* Correspondence Author

Avinash Pawar, Department of Management Sciences, Savitribai Phule Pune University, India

Rajesh Pahurkar, Department of Management Sciences, Savitribai Phule Pune University, India were taken up to improve the economy of India (Kolte et al., 2019).

India confronted with the balance of payment (BOP) crisis in the mid of 1991. It has affected the economic functions and raised to the deficit of Rs. 11384 crore. Hence, there was the need of the economy and country to focus on the macroeconomic policy of India to deal with this centralised issue of balance of payment. There was an increase in prices of imports during this time due to the oil shock in 1979, which has increased the cost of imports by two time and further shown the increasing trend in India at that time. Nevertheless, there was a global recession from the year 1980 to 1983, which affected India in terms of exports and revenues. In the period 1985 to 1990 , there was a trade deficit of Rs. 54204 crore, net invisible was Rs. 13157 crore and the balance of payment was Rs 41047 crore which formed a severe economic crisis in India

In the year of 1991, India faced the worst payment crisis since independence. It became worse after the Gulf war resulting in two-digit inflation. Further, the credit rating of India was relegated, and financial condition was degraded. At this point, India was on the verge of non-payment of loans and borrowings which were taken from international authorities. As a result, the net outflow of NRI deposits increased, and investors put up their hands to invest in India. So India fulfilled this situation by compromising gold reserve and agreed to terms and condition imposed by international authorities to get funds which would handle the economic situation. So it was a black time for India. For that, India has made many economic policies and reforming government agendas after 1991, even though in 2012-13, India faced a current account deficit problem (Mathew et al., 2013).

India's economic crisis of 1991 was mainly because of the balance of payment issues, which was a consequence of scarce reserves of foreign exchange for making payments. Across the literature on this crisis is attributed to various factors of higher fiscal deficit, higher debt component, higher interest rates, higher inflation, devaluation of currency, invasion of Kuwait by Iraq, USA's invasion in Iraq, resultant rise in oil prices, political instability in communist economies, and political instability in India. There was a lesser need for hard currencies to India because of payment in rupees to Eastern European Countries and USSR as per the terms. India USSR trade significantly rose post-1975. While less attention was concentrated towards reserves of other hard currencies and there was an increase in imports from western countries and as a result, foreign exchange reserves depleted. In 1991 , the condition was so critical that India had to pledge gold reserves for raising foreign exchange. India had devaluated rupee and had to amend economic policies as terms and conditions to get funding from 
the international monetary fund (Kolte \& Simonetti 2018).

The balance of payment crisis faced by India was because of higher expenditure and non-sustainable borrowings. The beginning of this crisis was stared in 1985, where India had problems in the balance of payment as import increases (India Before 1991, 2016). The macroeconomic factors involved for this crisis was that the current account deficit was elevated from 2.3 percent in 1990 to 3.1 percent in 1991 and the fiscal deficit rose from 7.33 percent in 1990 to 7.85 in 1991. It is realised that the annual average inflation was increased from 7.45 in the year 1989-90 to 10.25 in 1990-91, which became reached to the level of 13.75 in 1991-92. While the industrial growth rate decreased from 8.6 percent in 1990 to 8.2 percent in 1991, this has contributed to declining of the rate of gross domestic product (GDP) which was 6.5 percent in 1989and was decreased to 5.5 percent in 1991 and also the forex reserves which conserved to shield the import cost for two years were only stood at two and half months of imports. In quantifiable terms, the values of foreign exchange reserves of India in 1989 and 1990 had a significant difference. At the end of 1989, it was around Rs. 5277 crores however, by the completion of 1990; it was condensed to Rs. 2152 crore. While in the time frame of May 1991 and July 1991 the values of foreign exchange reserves fluctuated between Rs. 2500 crore and Rs. 3300 crore (Centre for Civil Society, 2016). Furthermore, the situation forced India to offer collateral security of 67 tons of gold to borrow loan from the International Monetary Fund (IMF) to deluge above the issue (Rangarajan, 2016).

The current account deficit was gradually increased from 2002-12, and as per the RBI's report, the current account deficit was the highest at $\$ 20$ Billion at the end of 2012. The value of crude imports and gold was at the peak, which helps in increasing the current account deficit. This was the awakening call for India, and soon India started to control the situation by reforming new economic policies and temporarily increased the prices of imports and by enhancing exports. Reserve Bank of India also helps by reforming monetary policies, and the government's initiative for foreign investors and NRIs led to stability over the current account deficit (RBI, 2017).

\section{LITERATURE REVIEW}

India faced a Balance of Payments (BOP) crisis at the culmination of the year 1980 due to the cause of non-sustainable borrowing and higher expenses. The current account deficit during the period from 1989 to 1991 was increased from INR 11350 crore to INR 17350 crore, which abridged the capacity for the financing of the deficit. Likewise, the trade deficit was amplified from Rs. 12400 crore to Rs. 16900 crore in the same period (Rajadhyaksha, 2013). The balance of payment crisis had broader economic and financial implications in the country. The significant causes of the balance of payment crisis in India are synthesisedwith the help of a review of the literature. It is deliberated in three parts which are causes of the balance of payment crisis of 1991, the balance of payment in 2012 and comparison of 1991 and 2012 crisis.

\section{A) Causes of the balance of payment crisis of 1991}

The literature on the balance of payment crisis of 1991 has deliberated on various causes which created economic problems and challenges in India.

Division of the soviet bloc: Before 1980's India trade with Soviet Bloc in terms of rupees, it means all the payment were made in rupees only. However, the disintegration of Eastern European countries and the introduction of Glasnost and Perestroika headed for termination of numerous rupee payment agreements in 1990-91. It has also generated severe consequences and political changes in Eastern Europe which affected the Indian currency and declined the flow of rupee and trade credits in 1990-91 which contributed to drop in India's exports (India Before 1991, 2016).

Iraq-Kuwait war: The crisis in the Gulf initiated with the incursion of Kuwait by Iraq in mid-1990. In this period, the crude oil prices raised rapidly, which affected the Indian economy on a broader range. As Iraq and Kuwait were the foremost sources of oil imports, India had to procure the oil at higher spot rates. It has forced India to spend more on oil imports as the condition of short term purchases with the spot rates must ensure the long term contracts at higher prices to maintain the oil supply. As an outcome, India lost most of the forex reserves led to a trade account deficit (Saxena, 2002).

Political uncertainty and instability: The Indian government was uncertain and unstable in the time frame of 1989 to 1991 , whichwas mentioned as a period of political uncertainty and instability. It is to highlight that; therewasa change of three coalition governments and three Prime Ministers during this a period in India which has mostly affected the government decision making and means of handling the crisis of balance of payment. Further, it has resulted in the loss of investors' confidence in the economy and country (Virmani, 2001).

The upsurge in external debt: The current account deficit exhibited the expanding trend and further turn into unstable and unsustainable after the middle of the year 1980. The financial deficit was managed with the financial support from the exterior sources like external commercial borrowing, and NRI deposits which were the major problem for the economy. (Pinto \& Zahir, 2004).

The escalation in non-oil imports: In the course of the period of the 1980s the trade deficit was increased due to increment in imports by 2.3 percent of GDP and insignificant growth of exports by merely 0.3 percent of GDP. In that total, there was a significant part of non-oil imports which constituted 91 percent,and remaining was constituted by oil. Thus, it is one of the majorelement leading to a rise in the trade deficit. The export of India was declining, and it was not competitive enough in the global market, which resulted in a lack of availability of foreign currency. Hence, India was unable to earn sufficient USD to compensate for imports. This situation has extended in the form of currency devaluation of India (Raghavan, 2013). 


\section{B) Balance of payment in 2012}

India has been experiencing an increase in the current account deficit in the balance of payments, especially since 2011-12. With net exports declining, India's balance of payments has come under pressure. The performance of balance of payments shows that in the first half of the financial year of 2011-12, the current account deficit which stands at the US dollar 36.4 billion increased to the US dollar 39.0 billion in the first half of 2012-13 (Kopparapu, 2011). Thus the current account deficit as a percent of GDP which was 4.0 per cent in the first half 2011-12 gradually increased to 4.6 percent of GDP in the first half of 2012-13 (RBI Press release, 2013). The devaluation of the currency of India has amplified the price of imports for the necessary commodities including medicines, fertilisers, iron ore and crude oil. This situation has impacted each commodity element that average Indian customer needs for their daily life (The Economist, 2013). Additionally, the global financial crisis in 2008 supplemented to this deficit, which created the economic slowdown and then shrunk the exports of the country. As a result, the deficit was increased to the level of 2.4 percent of GDP on the current account, which was impossible to manage with the small capital inflows. Therefore, to manage this situation and support the deficit on the current account, India had to pull out the US \$ 20 billion from foreign exchange reserves in 2008-09. Similarly, due to all these economic fluctuations, the current account deficit had been relatively high in 2011-12 and 2012-13. The upsurge in current deficit inclines to weaken the value of the currency by increasing the demand for US dollars. On this context in India, the current account deficit have decreased the value of rupee and raised the demand for US dollars in 2011- 12.Since the capital inflows in this year were not sufficient to financially support the current account deficit, the RBI had to take out US dollar 12.8 billion from its foreign reserves to meet the demand for US dollars (Srikumar, 2013).

\section{C) Comparison of 1991 and 2012 crisis}

In 1991 crisis, the situation was awful at that time as we were trapped from all sides and India had not a single escape plan to exit from that situation except accepting the demands and conditions of IMF and British government and because of that India had to bend down on his keens and had to export 67 ton of gold. However, in 2012, the situation is not as difficult as it was in 1991. It is due to the change in the fundamental economic structure, flexible exchange rates and immense depth in financial markets of India. Henceforth, the policies (LPG, Monetary, and Fiscal) that designed after 1991 crisis help India to build pillars in the economic and financial sector which firmly handle the current account deficit situation and because of the strong policies the government took sudden decisions to reduce current account deficit. The comparison between the economic crisis of balance of payment of 1991 and 2012 is based on the causes of both of this crisis in India. The major elements responsible for the crisis of 1991 were the disintegration of soviet bloc, the effect of the war between Iraq and Kuwait, uncertainty and instability political environment, upsurge in nonoil imports, increase in external debts, investor's loss of confidence, the sluggish progression of vital trading partners, and economic indiscipline. The maintenance of trade arrangement of Rupee with the Soviet Bloc was a significant element of total trade of India till 1980.
However, the disintegration of Eastern European countries and the initiation of Glasnost and Perestroika resulted in the termination of numerous payment provisions in rupees; hence, the trade credit flow of rupee was condensed in 1990-91. The exports of India to Eastern Europe was significant, in 1989 it was reduced to 19.30 percent from 22.10 percent. Further in the year 1991, it condensed to 17.90 percent,andfinally, in the year of 1992, it dropped to 10.90 percent (Kolte \& Daryani, 2018).

Based on the review and synthesis of the literature on the balance of payment crisis and its effect on economic factors, the researchers have the following research questions to discourse.

- What is the effect of balance of payment on capital account and current account of India? (Based on the balance of payment crisis of 1991 and 2012)

- What reforms have helped India to overcome the balance of payment crisis? (On the context of government policy decisions)

The researchers have endeavoured to address these research questions in the sections of analysis and discussions in the first part and then in findings and suggestions in the second part.

\section{RESEARCH METHODS}

This research study is fundamentally based on the secondary data and emphases on the review on the economic crisis of balance of payment faced by India in the year 1991 and 2012. Our study also deliberates on the understanding of the causes of the balance of payment crisis and further actions of economic reforms in India. This paper is descriptive and presents maiden findings on the financial crisis issue. The researchers have sourced the data from authenticated websites of Reserve Bank of India, national department reports, publications of government organisationsand scholarly publications in the journals. The data is filtered and analysed with different periods as per the research questions to derive the inferences of this study.

\section{RESULTS AND DISCUSSION}

India's current account deficit situation has been a concern for many years. There are two possible reasons that are the underlying causes for this situation: - an excess demand or supply shocks. For analytical purposes, let there be the hypothesis that a large current account deficit implies that the country's collective demand (addition of consumption and investment) which is considerably surpassed its aggregate domestic yield. The difficulty with this proposition is that the turmoil of 2011-12 happened when the growth rate of India fell to 6.50percent as opposed to 8.40percent recorded during the preceding year. As per the research conducted by the Indira Gandhi Institute of Development Research, it is derived that the Indian current account deficit situation behaves in a countercyclical manner meaning that the value for current account deficit increases when output falls and not when there is an increase in the demand. Thus, it can be statedthat India or the South Asian region is irregular. For

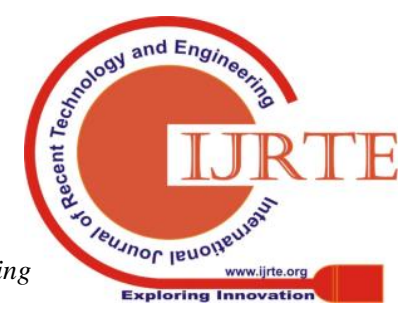


almost all other emerging markets, the current account deficit tends to be pro-cyclical, meaning that the value for current account deficit is connected to overconsumptioningood times. One of the reasons for overconsumption can be lower credibility of policy and the faith that the good times may not last long as predicted. It may lead to an increase in the value for the current account deficit at such times. Especially in developed countries, there is almost a display of such relation with income fluctuation. A countercyclical current account deficit in India suggests that external supply shocks are more dominant than excess demand factors. For exemplary purposes, if we consider that an external shock occurs and subsequently the price of oil increases, then this would lead to a fall in the gross domestic product, ands ubsequently, the value for current account deficit will increase. Another factor could be the export-led growth, meaning, if exports increase income,and then the current account deficit value will decrease. On the other side, if the export market crashes, then income would reduce, and the value for current account deficit would increase. If this flow of thought is continued, then in the financial year 2011-12, the year in which the highest value for current account deficit was observed (4.2 percent of the gross domestic product) a strident increase in oil prices and a reduction in growth was observed. This situation can be compared with 2007-08 when the value for the current account deficit was nearly 1.30 percent of the grossdomestic product of the country. This was the year in which high consumption, output growth and investment were observed, and another line of thought can be followed (Kapoor, 2016).
The further section of analysis and discussion is deliberated in two parts which are a balance of payment on capital, and current account of India and policy reforms were undertaken to overcome the balance of payment.

\section{A) Balance of payment on capital and current accounts}

In the context of analysis, it is hypothesised that the current account deficit is causedbecause of the costs that support excessive imports. A devaluation of rupee would increase the prices of imports and make exports economical for foreigners. Alternatively, this may prove to be a coarse mechanism in the Indian context wherein, oil and gold constitute a major part of imports. On the other hand, imported machinery and goods are inputs, and if the prices of such commodities increase, then, the cost of production would subsequently increase. Some alternatives for depreciation of the currency, in order to boost exports, would be to diversify export basket and the destination nations that these commodities go to, improving domestic supply conditions. Excessive volatility in the exchange market does not help export. Imports can be reduced by increasing their relative prices. A component of reason as to why demand is inelastic is that the prices are not allowed to adjust. Some nominal depreciation is always required in the Indian context (Singh, 2012). As a result trade deficit increased to 10.2 percent in 2011-12 as compared to 7.40percent of GDP during 2010-11. This deficit of trade was mainly on behalf of greater increase in imports comparative to exports (Economic Survey, 2012-13). The following table1shows the situation of the balanceof payment on the capital account of India.

Table 1: Balance of payment on the capital account of India (percent of GDP)

\begin{tabular}{|c|l|c|c|c|c|c|c|}
\hline No & \multicolumn{1}{|c|}{ Factors } & $\mathbf{2 0 0 7 - 0 8}$ & $\mathbf{2 0 0 8 - 0 9}$ & $\mathbf{2 0 0 9 - 1 0}$ & $\mathbf{2 0 1 0 - 1 1}$ & $\mathbf{2 0 1 1 - 1 2}$ & $\mathbf{2 0 1 2 - 1 3}$ \\
\hline 1 & External Assistance (Net) & 2.10 & 2.60 & 2.90 & 4.93 & 2.30 & - \\
\hline 2 & Commercial Borrowings (Net) & 22.60 & 7.00 & 2.80 & 11.80 & 10.30 & - \\
\hline 3 & Non-Resident Deposits (Net) & 0.20 & -4.30 & - & 3.18 & 11.90 & - \\
\hline 4 & Foreign Investment (Net) & 43.30 & 3.50 & 51.20 & 44.18 & 39.30 & - \\
\hline 5 & FDI (Net) & 15.90 & 17.50 & 18.80 & 7.10 & 22.10 & - \\
\hline 6 & Portfolio Investment (Net) & 27.40 & -15.00 & 32.40 & 37.20 & 17.20 & - \\
\hline 7 & Other Capital Flows (Net) & 39.70 & -9.70 & -13.10 & -10.36 & - & - \\
\hline 8 & Capital Account Total (Net) & 107.90 & 8.60 & 53.40 & 59.70 & 67.80 & - \\
\hline 9 & Use of Exchange Reserves & -92.20 & 20.10 & -13.40 & -13.10 & 12.80 & -3.80 \\
\hline
\end{tabular}

(Source: RBI, 2017)

As the table 1 shows the total inflow and outflow of the fund and its effect on the current account over the years.This indicates that there is larger effect on the crucial financial indicators of India.
On the other hand, in 2011-12 there was higher growth in imports of petroleum, oil and lubricant, gold and silver and machinery. As a result, India lost most of the forex reserves led to a trade account deficit. So, table 2 highlights the balance of payment on the current account of India.

Table 2: Balance of payment on current account of India

\begin{tabular}{l|c|c|c|c|c|c|c|}
\hline No & \multicolumn{1}{|c|}{ Items } & $\mathbf{2 0 0 7 - 0 8}$ & $\mathbf{2 0 0 8 - 0 9}$ & $\mathbf{2 0 0 9 - 1 0}$ & $\mathbf{2 0 1 0 - 1 1}$ & $\mathbf{2 0 1 1 - 1 2}$ & $\mathbf{2 0 1 2 - 1 3}$ \\
\hline 1 & Exports & 166.20 & 189.00 & 182.20 & 256.20 & 309.80 & 306.60 \\
\hline 2 & Imports & 257.60 & 307.60 & 300.60 & 383.50 & 499.50 & 592.20 \\
\hline 3 & Trade Balance & -91.50 & -118.60 & -118.40 & -127.30 & -189.90 & -195.70 \\
\hline & & -7.40 & -9.80 & -8.60 & -7.80 & -10.10 & -10.80 \\
\hline 4 & Invisibles (Net) & 75.70 & 89.90 & 79.90 & 79.30 & 111.60 & 64.90 \\
\hline
\end{tabular}




\begin{tabular}{|c|l|c|c|c|c|c|c|}
\multirow{2}{*}{} & Non-factor Services & 38.90 & 49.60 & 35.70 & 44.10 & 64.10 & - \\
\cline { 2 - 8 } & Investment Income & -5.10 & -4.00 & -8.00 & -17.90 & -16.00 & - \\
\cline { 2 - 8 } & Private Transfers & 41.70 & 44.60 & 52.30 & 53.10 & 63.50 & - \\
\hline 5 & Goods and Service Balance & -52.60 & -69.00 & -83.00 & -83.20 & -125.70 & -130.70 \\
\hline 6 & Current Account Balance (Net) & -15.70 & -28.70 & -38.40 & -48.10 & -78.20 & -87.80 \\
\hline & & -1.30 & -2.40 & -2.80 & -2.70 & -4.20 & 4.80 \\
\hline
\end{tabular}

(Source: RBI, 2017)

From the table 2, we have seen that imports are gradually increased over the exports. Moreover, in 2012-13 it went to the highest. Moreover, the trade balance was kept on increasing. Moreover, from all that current account deficit was increased. (Mukherjee, 2013).

\section{B) Policy reforms were undertaken to overcome the balance of payment}

The government has undertaken a strategy which is a combination of macroeconomic stabilisation and structural adjustments to effectively deal with the balance of payments. The stabilisation was essential in the short run to control the situation while structural reform is necessary for the long run. Following are the major policy initiative taken by governments.

1. Fiscal reforms: A crucial component to stabilise the situation was to renovate the fiscal policies. In 1991-92 budget government took some bold steps like decrease in fertiliser subsidy, elimination of subsidy on sugar, the abolition of cash compulsory support for exports, disinvestment of government's shares in public sector undertaking and restructure the taxes in customs, imports and exports. (Goyal, 2016).

2. Monetary reforms: Reserve bank of India (RBI) played the critical role in 1991-92 to reform monetary policies by reducing Statutory Liquidity Ratio (SLR) and Cash Reserve Ratio (CRR) to encourage banking sector and also gives leverages to banks to reposition branches, start specialised branches and establish controlling offices. RBI was given licenses to foreign banks and financial institutions. Governments also promote mutual funds and treasury bills (Gupta, 1998)

3. Industrial reforms: In the year 1991, the government of India has announced new policies for industries in which they promote industrial business by reducing restrictions on more than 18 industries in India based on the strategic intent, environmental concern and produces goods with exceptionally high import quality. This activity has eliminated around 80 per cent of the industry out of the licensing framework in India, which provided the base for implementation of broader economic reforms (Pandey, 2016). Furthermore, this achievement is possible by growing investment opportunities and the environment in the country (Harikrishnan, 2016). It is also needed to be considered that, the larger dependence on crude oil for can create many economic problems for the country hence it is necessary to find and use other alternative sources and forms of energy (Beckett, 2011). It is highlightedthat the reforms that have been introduced after 1991 have directed the growth in the average income of the Indian customers by five times (Mudgill, 2018).
4. Trade reforms: This was the major reform which helps India to take back on the track. Government reformed trade sector by making duty free imports and exports and created an environment which would stimulate the exports and at the same time ease the degree of government regulations and licensing control on foreign trade. It is necessary to have lower account gap by reducing the imports and building the import controls on select segments to better deal with the problem of trade, import and exports. This can help the economy by minimising the current account gap (Jain, 2016).

5. Public sector reforms: The government of India has taken public sector reform by offering a part of public sector equity to the public by undertaking limited disinvestment through financial institutions and mutual funds. It has also facilitated to elevate the non-inflationary developments and amending the sick Industrial Companies Act by bringing the public sector organisations within its purview (Vikraman, 2017).

6. Development reforms: In order to control the current account deficit in 2012 government was done some of the major policy reforms for development. The government has increased taxes on gold to balance the trade level, which weight down the rupee. Similarly, adopted the initiatives to pick up the merchandised exports and concessional dollar swaps for lenders to spur inflows in order to support the rupee. The provisions to have better monetary control over the liquidity in the market and helped to attract foreign investors by reducing government norms and allowed FDI (Foreign Direct Investment) in multi-brand retail, special economic zones, schemes for a software technology parks, schemes for biotechnology parks, and export-orientedunit schemes (Goyal, 2012).

The researcher has realised the effect of balance of payment on capital and current account of India and further the significance to address the issue with policy reforms to overcome the balance of payment. In the section of findings and suggestions, the researchers proposed the current economic situation, future remedies and auxiliary initiatives towards the economic aspects of the balance of payment.

\section{FINDINGS AND SUGGESTIONS}

India has considerably suffered on the economic side due to the balance of payment crisis in 1991 and was almost close to suffering another such crisis in the year 2012 (Karl, 2013). Together both of these crises have proceeded a role of catalyst for bringing the economic reforms in the country. Though the liquidity support can cure the effects of balance of payment in short-runbut economic reforms are the optimum way for enduring resolution for such a

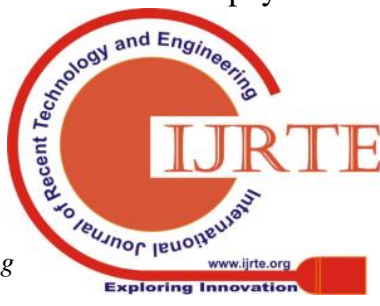


state of affairs. It will also assist in encouraging an environment of investment that aids for improvement of national domestic capabilities to rise exports and lessen the dependence on imports through substitution for the economic growth of the country (Joshua, 2016).

\section{A) Current economic situation}

The surge in imports of electronics and upsurge in the price of oil has increased the current account deficit to nearly 2 percent. The current account deficit in the balance of payments is US dollar 13.5 billion or 2 percent of gross domestic product. It is considerably higher than the US dollar 8 billion at the end of the quarter ended in December 2017. A closer look at the data indicates that the primary motive for the substantial increase in the current account deficit is the increase in prices of crude oil and petroleum products which contributes to 40 percent of India's product import. On the other side, the other majorconstituent is the services sector of India, which increases by approximately 17 percentper year. It was noticed mainly due to an increase in net earnings from software services exports. The private transfer receipts, which mainly represents remittances by overseas Indians, were approximately US dollar 17 billion, thus marking an increase of 16 percentevery year. For the capital account which is made up of overseas borrowings, NRI deposits and foreign investments, the value was USD 4.3 billion which although is lower than the USD 9.7 billion that was recorded in the third quarter of 2016-17. Similarly, the value recorded under portfolio investment was USD 5.3 billion of net flow for the third quarter of 2017-18 as against an outflow of USD 11.3 billion in the third quarter of last year due to net purchases in equity and debt markets. Net NRI deposits figure stood at USD 3.1 billion in the third quarter of 2017-18 against net repayments of USD 18.5 billion that were made last year. As for the overall condition, including the position in the capital account and current account in a surplus of USD 9.4 billion due to a USD 22 billion surplus in the capital account. (Nayak, 2018)

\section{B) Remedies for future}

The government must focus on remedies for the future as this kind of situation may be arises in future or other influential global factorsof world inflation and global crisis may affect the balance of payment of India. Some of the remedies can government should raise focused on are:

Address petroleum issue: The Government should be focused on alternatives to reduce consumption of petroleum products and deregulation of oil prices, which will slowly remove the subsidy. It is also necessary to put more taxes on excessive use of oil which bring in incremental pricing along with the promotion for growth of the use of renewable sources of energy.

Reduce gold demand: It is vital to promote national saving schemes and sovereign gold bond schemes and allocate quarter import quota to agencies and let them bid for the gold every quarter. Furthermore, review gold import every quarter to set the agenda for the future.

Export Diversification: Government must encourage people to do lots of exports by reducing taxes and government policies. In order to increase the forex reserve government should support people to find alternatives to import. Furthermore, taking initiatives for expanding opportunities for export and improvement of backward and forward linkage to domestic inputs and services. The government should increase import duties on luxury goods and non-essential items (e.g. luxury cars, TVs, mobiles, etc.) by a reduction in payments on external debt and an increase in investment by foreign investors.

Foreign remittances: The strategy to diversify the inflows of foreign remittances in stock, bonds, fixed deposits and real estate is to be implemented. The promotion to attract more Foreign Direct Investment (FDI) \&Foreign Institutional Investors (FII) must be done as India wants to focus on long term foreign direct investment for future economic growth. It is necessary to match FDI policy with import duties, in such a way that rise in import duties act as incentives to foreign direct investments in that particular sector. The government should allow FII to buy government bonds and also enhance the limit in investing government securities.

External borrowing: The government should be focused on reviewing external commercial borrowing (ECB)every quarter and allowed only in limited sectors like special economic zones, NGOs engaged in microfinance activities, infrastructure, innovations in renewable energy and multistate co-operative society engaged in manufacturing activities.ECB should not be used for investing in share market or real-estate market, acquiring another company, repayment of existing loans and general corporate purpose.

\section{C) Auxiliary initiatives}

The government should reduce expenditure revenue and increase expenditure on technologies which help in boosting exports. It is observedthat the short debt of India is nearly 25-30 percent of the overall debt, which is not desirable for the country. The short debt is higher in value and represents approximately 5 percent in the financial year 2002-2003. This increased level of short debt is because of higher credit trade, higher imports and lower exports. While the trade deficit has been financed by short term credit from previous few years but to resolve this problem, it is essential to restrict imports, replacing imports and advancing exports in the country (Baru, 2016). On the other side, it can also be realised only by growing the investment atmosphere in the country (Harikrishnan, 2016). In recent times, there has been an upsurge in the ranking for India for ease of doing business which indicates that the government is taking necessary actions to develop the economy and business in India. However, there is a need to have reforms related to the corruption, red-tape and political influence to increase the investments. Although domestic investments also play a crucial role in economic development. The domestic investment level in India is around 30 percent of gross domestic product. It is also to be noted that, the higher emphasis must be provided to empower a fair regulatory mechanism in the country which can promote more investment to substitute imports. Furthermore, the rupee trade agreements with the partner nations must be reinforced as India have realised the good results from the rupee trade agreement with USSR which can further be extended with other countries to reap more benefits. On similar lines, the establishment of multilateral agencies of partner nations for devising the credit facilities is must deal with the issue of balance of payment (Kolte \& Simonetti, 2018). 
The initiative to establish a New Development Bank (NDB) was made to deal with economic challenges. The NDB has a headquarters in china;hence, the relationship between China and India plays a crucial role in realising the benefits for the economy and country. However, due to the unrestrained relationship between India and China, it is not suggested to rely on NDB. On the same way, the Asian Development Bank (ADB) can also support the development of Asian economies. multilateral institutions working for developing nations, especially Asian nations, may be developed. It is also reiteratedthat the dependence on the crude-oil as a prime source must be reduced for economic affluence (Beckett, 2011).Transportation in India consumes the major proportion of crude oil, which is near to 50percent of the total petroleum consumption. The government of India is extensively working to develop concrete guidelines for the electric automotive industry. Similarly, the electrification of the entire railway system is also in the planning phase in India. These initiatives can help to reduce the dependence on crude oil in the transportation sector. Therefore, improving rail connectivity and public transportation would support the reduction in oil consumption in India. The demand for gold is higher in India and spends around US Dollar 52.50 billion in gold imports in the financial year 2012-13; hence; Gold imports must be minimised by formulating a policy. It is realised that almost 30 percent of external debt is composed of commercial borrowings by the corporate, which is must be regulated and retained within limits. It is comprehended that the reforms that have been introduced after 1991 have led to increase in the average income of the Indian customers by nearly five times which is a significant contribution for the country (Mudgill, 2018). As a citizen of the country, if people support the products made India for their consumption as against imports, it would help to preserve the foreign exchange reserves for the country (Mohanty, 2013). Further, it will upkeep the domestic investment, which leads to increase the national production capacity and ultimately contributes to becoming a self-reliant and self-sustainable country.

\section{CONCLUSION}

The overview of the balance of payment crisis and current account deficit shows the causes, impacts and remedies of the crisis, and also it includes the study of measures to control future threats and how to handle a crisis if occurred in future. It also focuses on the impact of the current account deficit and its necessity to reduce it. India faced a terrible situation in 1991, which was awful, but it also gave the lesson to control such a situation. It also added reformation of many sectors and government's policies which helps in growing primary, industrial and service sector. The most significant factors that came out after the 1991 crisis is understanding of risk management and economic indicators in respect of domestic and global market trade. India was economically suffered by the balance of payment crisis in 1991 and during the 2012-13 tenure, was close to suffering another severe crisis. The regular pressure on the balance of payment crisis hasbeen skilfully managed through policy changes. While the balance of payment came under stress since 2011-12, as emphasised by the government that, the situation is not as serious and severe as it was in 1991. This is because of fundamental changes in economic structure, flexible exchange rate and Hence, it is suggested to have an association with the other

greater depth in financial markets. However, there is a need to reduce current account deficit in the long run to accelerate efforts towards structural reforms that support in boosting the competitive market, advances growth potential, and brings stable and sustainable flows into the economy.

\section{REFERENCES}

1. Baru, S. (2016). 1991: How PV Narasimha Rao Made History. Aleph Book Company.

2. Beckett, P. (2011). The 1991 Speech Manmohan Singh Should Make Today. The Wall Street Journal.

3. Centre for Civil Society. (2016). 1991 crisis. Retrieved from India Before 91. (2012-13). Economic Survey.

4. Goyal, A. (2012). The future of financial liberalization in South Asia Asia-Pacific Development Journal, 19(1), 63-96.

5. Goyal, S. (2016). Economic reforms in India. ACADEMICIA: An International Multidisciplinary Research Journal, 6(3), 123-128.

6. Gupta, S. P. (1998). Post-Reform India: Emerging Trends. Allied Publishers.

7. Harikrishnan, C. (2016). 1991 reform was Narasimhanomics. The Economic Times. India before 1991.

8. International Journal of Creative Research Thoughts, 6 (1), 54-64.

9. Jain, A. (2016). 25 years on, Manmohand Singh on rupee, reforms and resolution. The Economic Times.

10. Kapoor, R. (2016). India: Rise of the Elephant?

11. Karl, D. J. (2013). India's Economy: Time to Revisit 1991. The Diplomat.

12. Kolte, A., \& Daryani, A. (2018). A study on India's Balance of Payment difficulties of 2012. International Journal of Research in Social Sciences, 8 (6(1)), 511-516.

13. Kolte, A., \& Simonetti, B. (2018). A contrary view on Indian Economic Crisis of 1991. International Journal of Creative Research Thoughts, 6 (1), 54-64

14. Kolte, A., Siggia, D., Veer, N., and Daryani, A. (2019). Critical Exploration of Indian Economic Reforms of 1991: a lesson for Developing Economies. International Journal of Engineering and Advanced Technology, 8 (5S3), 490-500.

15. Kopparapu, S. (2011). Is India on the verge of another balance of payment crisis?

16. Mathew, J., Vijaykumar, N. V., \& Jacob, E. (2013). Balance of payment crisis in India: What the figures say. Arthshastra Indian Journal of Economics \& Research, 2(5), 14-26.

17. Mohanty, D. (2013). Perspectives on India's Balance of Payment.

18. Mudgill, A. (2018). Since 1991, Budget size grew 19 times, economy 9 times, your income 5 times. The Economic Times.

19. Mukherjee, S. (2013). The Problem of Widening Current Account Deficit of India.

20. Nayak, G. (2018). Current Account Deficit Widens to 2\% of GDP on higher oil Inport Bill.

21. Pandey, V. (2016). 4 Reforms That Pulled India Back after It Ran Out of Money in 1991. The Economic Times.

22. Pinto, B., \& Zahir, F. (2004). India: why fiscal adjustment now. The World Bank.

23. Raghavan, T. S. (2013). Two PMs and a countdown to financial crisis The Hindu.

24. Rangarajan, C. (2016). How India banked on reforms. The Business Line.

25. RBI Press release. (2013). Developments in India's Balance of Payments during the Fourth Quarter.

26. RBI. (2017). Handbook of Statistics on Indian Economy. Retrieved from https://rbi.org.in/

27. Saxena, V. C. (2002). What caused the 1991 Currency Crisis in India? IMF.

28. Singh, D. C. (2012). A Comprehensive Study of India's Current Account Deficit and the Need to Reduce it.

29. Srikumar, D. U. (2013). The Current Account Deficit in India Some Facts, Implications and Suggestions to Curtail the Deficit.

30. The Economist. (2013). The reckoning. The Economist.

31. Vikraman, S. (2017). In fact: RBI head and crisis manager during 1991 BOP turmoil. The Indian Express.

32. Virmani, A. (2001). India's BoP Crisis and External Reform. 